\title{
Povidone-iodine versus normal saline solution in preoperative vaginal cleansing before office hysteroscopy: a randomized controlled trial
}

\author{
Ahmed M. Abbas ${ }^{1 *}$, Asmaa S. Shaltout ${ }^{2}$, Shymaa S. Ali ${ }^{1}$, Armia Michael ${ }^{1}$, \\ Ahmed Altraigey $^{3}$, Laila E. Abdelfatah ${ }^{4}$
}

\begin{abstract}
${ }^{1}$ Department of Obstetrics and Gynecology, ${ }^{2}$ Department of Medical Microbiology and Immunology, Faculty of Medicine, Assiut University, Egypt

${ }^{3}$ Department of Obstetrics and Gynecology, Faculty of Medicine, Benha University, Egypt

${ }^{4}$ Department of Obstetrics and Gynecology, Faculty of Medicine, Aswan University, Egypt
\end{abstract}

Received: 17 October 2017

Accepted: 17 November 2017

\section{*Correspondence:}

Dr. Ahmed M. Abbas,

E-mail: bmr90@hotmail.com

Copyright: (c) the author(s), publisher and licensee Medip Academy. This is an open-access article distributed under the terms of the Creative Commons Attribution Non-Commercial License, which permits unrestricted non-commercial use, distribution, and reproduction in any medium, provided the original work is properly cited.

\section{ABSTRACT}

Background: Hysteroscopy is well-thought-out the gold standard for assessing the uterine cavity, and now can be done as an office process due to enhanced endoscopic advances with no need to in-patient admission. Objective of the present study was to compare the difference in the rate of postoperative vaginal irritation symptoms and postoperative infections after using povidone iodine (PI) and normal saline (NS) solution in vaginal cleaning before outpatient office hysteroscopy $(\mathrm{OH})$.

Methods: Women attended to the hospital for diagnostic $\mathrm{OH}$ were included for present study. Eligible women were randomly allocated in a 1:1 ratio to two groups. Group I "PI group" women exposed to PI for vaginal cleansing before hysteroscopy, and group II "NS group" women exposed to the NS solution for vaginal cleansing. The primary outcome of the study was to compare the difference in the rate of postoperative vaginal irritation symptoms and postoperative infections in both groups.

Results: The mean age of the study participants was $34.26 \pm 4.14$ years for NS group compared to $35.22 \pm 4.01$ years for PI group $(\mathrm{p}=0.652)$. The PI group reported higher rate of vaginal irritation than NS group with no statistically significant difference between the two groups $(\mathrm{p}=0.179)$. Both groups were similar in postoperative fever, urinary tract infection and vaginitis $(\mathrm{p}>0.05)$.

Conclusions: This study concluded that preoperative vaginal disinfection at the time of $\mathrm{OH}$ with a NS solution is less frequently causing postoperative vaginal irritation symptoms. Additionally, it is as effective as the usual agent (PI) in preventing postoperative infections.

Keywords: Disinfection, Hysteroscopy, Povidone iodine, Saline

\section{INTRODUCTION}

Hysteroscopy is well-thought-out the gold standard for assessing the uterine cavity, and now can be done as an office process due to enhanced endoscopic advances with no need to in-patient admission. ${ }^{1-3}$ Viewing the uterine cavity directly has an important benefit over the other blind or indirect diagnostic approaches. ${ }^{4}$ Even though, hysterosalpingography (HSG) was reported to have the same advantage and accuracy as hysteroscopy in the diagnosis of normal and abnormal uterine cavities, the cause of the intrauterine filling defects is more precisely exposed by hysteroscopy. ${ }^{4}$ Recent studies have revealed a correlation of only $65 \%$ between uterine cavity filling 
defect detected with HSG compared with those established with hysteroscopy. ${ }^{5}$

The povidone iodine (PI) is an antiseptic solution containing polyvinyl pyrrolidone with water, iodide, and $1 \%$ available iodine with bactericidal capability against a wide range of microbes. ${ }^{6}$ It is typically used as a skin and vaginal disinfectant to avoid postoperative infections. On the other hand; it may lead to significant irritation to the vaginal mucosa; and it can cause allergic reactions in females with iodine hypersensitivity. ${ }^{7}$

The normal saline (NS) is an effective cleaning solution and doesn't have any damage effect on healthy tissue. ${ }^{8}$ It is accessible, non-irritant, and less expensive in contrast to PI. ${ }^{9}$ Previous studies proposes that the mechanical cleaning of the vagina by NS solution had the same effectiveness in anticipation of postoperative infection. ${ }^{10,11}$

This study aims to compare the difference in the rate of postoperative vaginal irritation symptoms and the rate of postoperative infections after using PI and NS solution in vaginal cleaning before office hysteroscopy.

\section{METHODS}

The current study was a single-blinded, randomized clinical trial registered at (ClinicalTrials.gov: NCT02713074) comparing the efficacy of cleansing the vagina with PI versus NS on the rate of postoperative vaginal irritation symptoms and postoperative infections among women scheduled for office hysteroscopy. The institutional ethical review board approved the study. The participants were engaged from the Outpatient Gynecological Clinic of the aforementioned hospital between the $1^{\text {st }}$ of October 2016 and the $31^{\text {st }}$ of May 2017.

\section{Eligible participants}

All eligible candidates who presented to Assiut University Outpatient Gynecology clinics referred for office hysteroscopy unit were asked to contribute in the study. Women who had manifestations of vaginal infections (itching, discharge), diabetes, current or previous urinary tract infection, used antifungal or antiprotozoal drugsin the last 15 days prior to hysteroscopy and used broad-spectrum antibiotics or corticosteroids in the previous 15 days patients were excluded. Additionally, those who would undergone operative hysteroscopy and those who had manifestations indicative of endometriosis (severe dysmenorrhea, deep dyspareunia or chronic pelvic pain) were excluded.

\section{Randomization}

Randomization was done by a computer-generated table of random numbers with allocation disguise. Allocation was done using aserially-numbered closed opaque envelope and had a card noting the intervention type inside. Counselling for eligible women was done before enrolment. Once the allocation has been done, it could not be changed. Preparation and categorization of the consecutively numbered covers were done by an investigator who did not take part in assessing participants either before enrolment or in the follow-up stage.

\section{Intervention}

Eligible women were randomized in a 1:1 ratio to two groups. Group I "PI group" women exposed to PI (Betadine7.5\%, Pharma Care, Egypt) for vaginal cleansing before hysteroscopy and group II "NS group" women exposed to the standard NS solution (Sod. Chloride $0.9 \%$, Nile, Egypt) for vaginal cleansing. Two sponges with the same size and type were utilized for cleaning by both preparations.

Evacuation of the bladder immediately before the procedure by metal urinary catheters in both groups then immediately removed. Additionally; matching instrumentations were used in both groups in the study (Tenaculum, Cusco's Speculum).

\section{Study outcomes}

The primary outcome of the study was to compare the difference in the rate of postoperative vaginal irritation symptoms after using PI and NS for vaginal cleansing before hysteroscopy. The secondary outcomes included the incidence of postoperative fever $\geq 38^{\circ} \mathrm{C}$ during the first 24 hours post-operatively, urinary tract infections, candidal vaginitis and bacterial vaginosis at 1 week postprocedure.

\section{Follow-up schedule}

All women were informed not to use any vaginal douches after micturition during the first day. All patients were questioned 24 hours postoperatively to be asked about the vaginal irritation symptoms as discharge, itching, soreness, burning and dryness. Then all patients of both groups had come back to hospital 7 days postoperatively to be questioned for presence of abnormal discharge, urinary tract infection manifestations (burning micturition, dysuria, and frequency) and fever.

The required sample size was calculated based on previous study assessing the rate of vaginal irritation symptoms with PI before gynecological laparoscopy. In the study of Ali et al, the rate of vaginal irritation symptoms in the PI group was $44.53 \% .{ }^{12}$ A sample size of at least 70 women with $80 \%$ power and $\alpha$ error of 0.05 was needed in each group to detect $50 \%$ decrease in the vaginal irritation symptoms with the use of NS (Odds ratio $=2.8$ ). Assuming $10 \%$ drop-out rate in follow up, so 77 women were included in each arm (OpenEpi, Version 3, open source calculator-SSMean). 


\section{Statistical analysis}

The data was collected and entered into a MicrosoftAccess database and was analyzed using the Statistical Package for Social Science (SPSS Inc., Chicago, version 21). The demographic characteristics and baseline data were compared between the groups. The outcome variables were calculated using a paired- $t$ test to compare continuous variables and using an independent-t-test between groups. For dichotomous variables, chi-square was used to estimate the significance value. For analysis, $\mathrm{p}<0.05$ was considered to be significant.

\section{RESULTS}

One-hundred eighty-four women were approached to participate in the study. Thirty women have been excluded: eighteen women had a lower genital tract infection. Six women received antibiotics within one week prior to hysteroscopy. Moreover, six women declined participation in the study. We randomly assigned the remaining 154 women into both groups. At the end of the study, four women in PI group and three women in NS group were lost to follow-up and not included in the final analysis.

Table 1: Baseline characteristics of the study participants.

\begin{tabular}{|c|c|c|c|}
\hline & $\begin{array}{l}\text { Group I, } \\
\text { PI }(n=73)\end{array}$ & $\begin{array}{l}\text { Group II } \\
\text { NS }(n=74)\end{array}$ & $\begin{array}{l}\text { p- } \\
\text { value }\end{array}$ \\
\hline \multicolumn{4}{|l|}{ Age (years)\# } \\
\hline Mean \pm SD & $34.26 \pm 4.14$ & $35.22 \pm 4.01$ & 0.652 \\
\hline \multicolumn{4}{|l|}{ Residence $^{\mathrm{I}}$} \\
\hline Rural & $24(32.9)$ & $19(25.7)$ & \multirow{3}{*}{0.203} \\
\hline Semi-urban & $37(50.7)$ & $34(45.9)$ & \\
\hline Urban & $12(16.4)$ & $21(28.4)$ & \\
\hline \multicolumn{4}{|l|}{ Education $^{I}$} \\
\hline Illiterate & $25(34.2)$ & $19(25.7)$ & \multirow{3}{*}{0.171} \\
\hline Primary & $35(47.9)$ & $38(51.3)$ & \\
\hline Secondary & $5(6.9)$ & $10(13.5)$ & \\
\hline University & $8(11)$ & $7(9.5)$ & \\
\hline Parity\# & $4.35 \pm 1.95$ & $4.21 \pm 2.40$ & 0.574 \\
\hline Contraceptive use $\mathrm{f}^{\mathrm{I}}$ & $61(83.6)$ & $63(85.1)$ & 0.120 \\
\hline $\mathrm{BMI}^{\#}$ & $22.9 \pm 1.7$ & $21.8 \pm 2.1$ & 0.712 \\
\hline $\begin{array}{l}\text { Operative time } \\
\text { (minutes) }^{\#}\end{array}$ & $15.19 \pm 3.78$ & $15.49 \pm 3.79$ & 0.071 \\
\hline
\end{tabular}

PI povidone-iodine, NS normal saline ( $\mathrm{f})$ Data are expressed as number (\%); (\#) Data are expressed as mean \pm standard deviation

The demographic data of the two groups are shown in Table 1. Both groups were quite similar in all demographic criteria. The mean age of the study participants was $34.26 \pm 4.14$ years for NS group compared to $35.22 \pm 4.01$ years for PI group $(\mathrm{p}=0.652)$.

The postoperative vaginal irritation symptoms which occurred in the first 24 hours are listed in Table 2 for both study groups. Collectively, both groups reported similar rate of vaginal irritation symptoms with no statistical significant difference $(\mathrm{p}=0.179)$.

Table 2: Postoperative vaginal irritation symptoms in both study groups.

\begin{tabular}{|c|c|c|c|c|c|}
\hline \multirow{2}{*}{$\begin{array}{l}\text { Postoperative } \\
\text { vaginal } \\
\text { irritation } \\
\text { symptoms }\end{array}$} & \multicolumn{2}{|c|}{$\begin{array}{l}\text { Group I } \\
\text { PI }(n=73)\end{array}$} & \multicolumn{2}{|c|}{$\begin{array}{l}\text { Group II } \\
\text { NS }(n=74)\end{array}$} & \multirow{2}{*}{$\begin{array}{l}\mathrm{p}- \\
\text { value }\end{array}$} \\
\hline & No. & $(\%)$ & No. & $(\%)$ & \\
\hline Burning & 6 & 8.2 & 4 & 5.4 & \\
\hline soreness & 4 & 5.5 & 1 & 1.4 & \\
\hline Dryness & 2 & 2.7 & 2 & 2.7 & \\
\hline Swelling & 2 & 2.7 & 1 & 1.4 & \\
\hline Itching & 4 & 5.5 & 4 & 5.4 & \\
\hline Vaginal pain & 0 & 0 & 2 & 2.7 & \\
\hline Total & 18 & 24.3 & 14 & 19.2 & 0.179 \\
\hline
\end{tabular}

PI povidone-iodine, NS normal saline

The postoperative febrile morbidity and infection rate in both groups were reported in Table 3 and shown that both groups were quite similar in urinary tract infection $(p=0.179)$, vaginal candidiasis $(p=0.214)$, and bacterial vaginosis $(\mathrm{p}=0.137)$. No cases of postoperative fever in both groups.

Table 3: Postoperative infections in both study groups.

\begin{tabular}{|c|c|c|c|c|c|}
\hline & \multicolumn{2}{|c|}{$\begin{array}{l}\text { Group I } \\
\text { PI }(n=73)\end{array}$} & \multicolumn{2}{|c|}{$\begin{array}{l}\text { Group II } \\
\text { NS (n=74) }\end{array}$} & \multirow{2}{*}{$\begin{array}{l}\text { p- } \\
\text { value }\end{array}$} \\
\hline & No & $(\%)$ & No & $(\%)$ & \\
\hline $\begin{array}{l}\text { Postoperative } \\
\text { fever }^{\mathrm{a}}\end{array}$ & 0 & 0 & 0 & 0 & ---- \\
\hline $\begin{array}{l}\text { Urinary tract } \\
\text { infection }^{\mathrm{b}}\end{array}$ & 4 & 5.5 & 6 & 8.1 & 0.179 \\
\hline $\begin{array}{l}\text { Vaginal } \\
\text { candidiasis }^{\mathrm{b}}\end{array}$ & 2 & 2.7 & 3 & 4.05 & 0.214 \\
\hline $\begin{array}{l}\text { Bacterial } \\
\text { vaginosis }^{\mathrm{b}}\end{array}$ & 4 & 5.5 & 2 & 2.7 & 0.137 \\
\hline
\end{tabular}

PI povidone-iodine, NS normal saline; ${ }^{a}$ Post-operative fever within first 24 postoperative; ${ }^{b}$ Other types of infection occurred one week postoperative

\section{DISCUSSION}

To the best of our knowledge, no prospective randomized clinical trial has been done or registered to compare PI and NS solution before office hysteroscopy.

In the present study we documented that vaginal cleansing with NS solution before office hysteroscopy can decrease the hazard of vaginal irritation symptoms which can be induced by PI use with no significant consequence on febrile morbidity or postoperative infections.

Preoperative vaginal cleansing with an antiseptic agentis a routine procedure before hysteroscopy, as vaginal scrub reduces the rate of postoperative infection at the time of 
surgery. ${ }^{13,14}$ The most common used solutions are PI and chlorhexidine solutions. ${ }^{15}$

Till now, PI is the only approved agent for preoperative vaginal cleansing. Though, there are considerable explanations to consider chlorhexidine gluconate solutions for patients with iodine allergy. ${ }^{7} \mathrm{PI}$ is the frequently used antiseptic for vaginal disinfection as a consequence of the well-known antimicrobial effect of iodine. But it's more sensitizing and irritating than other surgical disinfection solution when applied to the skin and mucous membranes. ${ }^{16}$

Though, the American congress of obstetrics and gynecology (ACOG) said that PI is not the perfect agent for preoperative vaginal disinfection. ${ }^{7}$ Iodine can be absorbed through the vaginal mucosa as its nonkeratinized epithelium and can lead to serious risks in patients with significant iodine allergy as it can be absorbed after 2 minutes of contact between PI and the vaginal mucosa. ${ }^{17}$ Furthermore, in normal vaginal $\mathrm{pH}$ (3.8-4.5), iodine's antiseptic properties are reduced, and iodophors are deactivated in the existence of blood. ${ }^{18}$

As there is no protective keratin layer and mucous glands at the vagina mucosa, it is more liable to irritation, mainly with vaginal antimicrobial agents. ${ }^{18}$ Our results are in agreement with this ACOG recommendations. The outcomes of our study documented that the postoperative vaginal irritation symptoms occurred in $24.3 \%$ of women in the PI group versus $19.2 \%$ of women in the NS solution group with no significant statistical difference $(\mathrm{p}=0.179)$.

The NS is used as an intravenous isotonic solution and for cleaning wounds. It is a mild but effective disinfection agent and will not harm normal tissue, unlike many stronger antiseptics..$^{9}$ It is available and less expensive in compared to PI.

In the area of assisted reproductive technology; Van et $\mathrm{al}^{19}$ revealed that the infection rates with NS solution are similar to PI when used as for vaginal preparation before oocyte retrieval. Additionally, Amstey et al evidenced that NS solution can have the same efficacy as PI in the prevention of postoperative infections after vaginal surgery. ${ }^{10}$ This matches with our results as the incidence of the overall postoperative genital tract and urinary tract infections were not statistically different in both groups.

Additionally, Lewis et al reported in their study that the Baby shampoo has the same effectiveness as PI in avoiding the postoperative infections if used for vaginal disinfection before minimally invasive gynecological processes. ${ }^{20}$ They documented that, the postoperative infection rate in PI group was $14.6 \%$ versus $11.8 \%$ in the baby shampoo group $(\mathrm{p}=0.52)$. Furthermore, baby shampoo is less irritant and less expensive than PI.
On the other hand, Kjölhede et al stated that NS increases the risk of postoperative infections therefore, it should not be used for vaginal disinfection before vaginal hysterectomy. ${ }^{11}$ This is a different result from our study and could be explained by the type of surgery as vaginal hysterectomy is a long operation. Also, the study was retrospective with high likelihood of bias. No recording of postoperative vaginal irritation symptoms despite using chlorhexidine gluconate in comparison with NS, which is known to be much more irritant than PI.

The strengths of our study include that it was a singleblind, randomized clinical trial with all women were blinded of the group assignment. Additionally, we were able to recruit our calculated sample size for achieving sufficient power to detect a clinically significant difference in our primary outcome. The limitations in our study were lack of microbiological assessment of vaginal discharge or urine analysis to be confident from the diagnosis of postoperative infections. Also, we didn't report the women's satisfaction rate with the overall procedure at the end.

\section{CONCLUSION}

The present study recommends preoperative vaginal disinfection at the time of office hysteroscopy with a NS solution as it is less frequently causing postoperative vaginal irritation symptoms, in addition it is as effective as (PI) in preventing postoperative infections.

\section{Funding: No funding sources \\ Conflict of interest: None declared \\ Ethical approval: The study was approved by the Institutional Ethics Committee}

\section{REFERENCES}

1. Brown SE, Coddington CC, Schnorr J, Toner JP, Gibbons W, Oehninger S. Evaluation of outpatient hysteroscopy, saline infusion hysterosonography and hysterosalpingography in infertile women: a prospective, randomized study. Fertil Steril. 2000;74:1029-34.

2. Shushan A, Rojansky N. Should hysteroscopy be a part of the basic infertility workup? Hum Reprod. 1999;14 (8):1923-4.

3. Gordts S, Campo R, Puttemans P. Investigation of the infertile couple. Hum Reprod. 2002;17(7):16847.

4. Prevedourakis C, Loutradis D, Kalianidis C, Makris $\mathrm{N}$, Aravantinos D. Hysterosalpingography and hysteroscopy in female infertility. Hum Reprod. 1994;9(12):2353-5.

5. Wang CW, Lee CL, Lai YM, Tsai CC, Chang MY, Soong YK. Comparison of hysterosalpingography and hysteroscopy in female infertility. J Am Assoc Gynecol Laparosc. 1996;3(4):581-4.

6. Abdel Badee AY, Ali MK, Abbas AM, Shazly SA. Evaluation of povidone Iodine $10 \%$ versus $7.5 \%$ 
hand scrub in cesarean section wound infections: A prospective trial. IJOG. 2014;2(3):45-51.

7. American College of Obstetricians and Gynecologists. Solutions for surgical preparation of the vagina. Committee Opinion No. 571. Obstet Gynecol. 2013;122:718-20.

8. Najafian A, Fallahi S, Khorgoei T, Ghahiri A, Alavi $A$, Rajaei $M$ et al. Role of soap and water in the treatment of wound dehiscence compared to normal saline plus povidone-iodine: A randomized clinical trial. J Educ Health Promot. 2015;4:86.

9. Salami, AA, Imosemi IO, Owoeye OO. A comparison of the effect of chlorhexidine, tap water and normal saline on healing wounds. Int J Morphol. 2006;24(4):673-6.

10. Amstey MS, Jones AP. Preparation of the vagina for surgery. A comparison of povidone-iodine and saline solution. JAMA. 1981;245:839-41.

11. Kjølhede, Halili S, Löfgren M. Vaginal cleansing and postoperative infectious morbidity in vaginal hysterectomy. A register study from the Swedish National Register for Gynecological Surgery. Acta Obstet Gynecol Scand. 2011;90(1):63-71.

12. Ali MK, Abbas AM, Abdalmageed OS, Abdelmagied AM, Abdel-Ghany MF, Khodry MM. Comparison between povidone-iodine versus normal saline solution in preoperative vaginal cleansing before short duration gynecological laparoscopy: a randomized clinical trial. World J Laparoscop Surg. 2017 (Article in press).

13. Culligan PJ, Kubik K, Murphy M, Blackwell L, Snyder J. A randomized trial that compared povidone iodine and chlorhexidine as antiseptics for vaginal hysterectomy. Am J Obstet Gynecol. 2005;192:4225.

14. Haas DM, Morgan S, Contreras K. Vaginal preparation with antiseptic solution before cesarean section forpreventing postoperative infections. Cochrane Database Syst Rev. 2014;12:CD007892.

15. Nagasawa $M$, Hayashi $H$, Nakayoshi $T$. In vitro evaluation of skinsensitivity of povidone-iodine and other antiseptics using a three dimensional human skin model. Dermatology. 2002;204(Suppl 1):10913.

16. Niedner R. Cytotoxicity and sensitization of povidone-iodine and other frequently used antiinfective agents. Dermatology. 1997;195(suppl 2):89-92.

17. Vorherr H, Vorherr UF, Mehta P, Ulrich JA, Messer RH. Vaginal absorption of povidone-iodine. JAMA. 1980;244:2628-9.

18. Mangram AJ, Horan TC, Pearson ML, Silver LC, Jarvis WR. Guideline for prevention of surgical site infection, 1999. Hospital Infection Control Practices Advisory Committee. Infect Control Hosp Epidemiol. 1999;20:250-78,279-80.

19. VanOs HC, Roozenburg BJ, Janssen-CaspersHA, Leerentveld RA, Scholtes MC, Zeilmaker GH, et al. Vaginal disinfection with povidone-iodine and the outcome of invitro fertilization. Hum Reprod. 1992;7:349-50.

20. Lewis LA, Lathi RB, Crochet P, Nezhat C. Preoperative vaginal preparation with baby shampoo compared with povidone-iodine before gynecologic procedures. J Minim Invasive Gynecol. 2007;14:7369.

Cite this article as: Abbas AM, Shaltout AS, Ali SS, Michael A, Altraigey A, Abdelfatah LE. Povidoneiodine versus normal saline solution in preoperative vaginal cleansing before office hysteroscopy: a randomized controlled trial. Int J Reprod Contracept Obstet Gynecol 2018;7:5-9. 